\title{
Palavras do editor
}

Este é o primeiro fascículo do volume 37 da revista TRANS/FORM/ $A C ̧ \tilde{A} O$, referente aos meses de janeiro a abril. É uma coletânea variada de temas das ciências humanas e filosofia que conta com 11 artigos inéditos e duas resenhas. Ainda que organizado por mim, este fascículo teve seus artigos e resenhas selecionados pela editora anterior Profa. Dra. Clélia Aparecida Martins, que foi editora do biênio 2012 - 2013. Nele o leitor encontrará textos de autores nacionais e estrangeiros dedicados aos mais diversos temas, que vão desde uma análise sobre a relação entre música e matemática, do ponto de vista da história da ciência, até um interessante texto sobre estética e política, visando um debate contemporâneo sobre as formas de representação. Isso reflete uma importante característica de nossa revista, ou seja, sua versatilidade informativa. Isso quer dizer que apesar de ser voltada especialmente para a publicação de textos de história da filosofia, a revista ainda assim possui uma enorme abertura à produção humanística em geral e um grande respeito pelas diversas tendências do pensamento.

Fui indicado para ser o novo editor desta revista para o biênio de 2014 - 2015. Por esse motivo gostaria de agradecer imensamente a todo o Departamento de Filosofia da Faculdade de Filosofia e Ciências (FFC) da UNESP de Marília por esse voto de confiança. Gostaria de agradecer também a todos os autores pela preferência em publicar na TRANS/FORM/AÇÃO. Registro aqui meus agradecimentos à Profa. Dra. Clélia Aparecida Martins, que de modo tấo competente atuou como editora da revista nesses últimos dois anos. Agradeço à estagiária da revista, Renata Alonge, por sua imensa colaboraçáo nesse período de transição; ao CNPq pelo auxílio financeiro concedido à editoração da revista e ao Programa de apoio às Publicaçóes 
Científicas da Pró-reitoria de Pesquisa da UNESP (PROPe) pela verba anualmente concedida para esse fim; a todo o corpo editorial, e especialmente ao Prof. Dr. Ubirajara Rancan de Azevedo Marques por todo o auxílio em suas horas vagas; à Maria Rosangela de Oliveira e Edevaldo Donizeti dos Santos, do Laboratório Editorial da FFC da UNESP de Marília, pela competência e agilidade com que nos auxilia na editoração, e a todos que de uma forma ou outra contribuíram com este fascículo e com os próximos que ainda virão. Tenho certeza de que com a ajuda de todos manteremos a qualidade, liberdade de pensamento e versatilidade informativa que fazem da TRANS/FORM/ $A C ̧ \tilde{A} O$ a revista que ela é hoje.

Kleber Cecon

Editor

Marília, abril/2014 